\title{
PENARIKAN BARANG YANG MENJADI OBYEK SEWA BELI DALAM HAL PEMBELI SEWA WANPRESTASI
}

\section{PUTU SUMIASI}

\begin{abstract}
The article entitled The Withdrawal of the Leasing Object in the event of Customer's Default in Payment. The main issue discussed is that whether the withdrawal of the leasing object is acceptable by the law in the event of customer's default in payment.

The research in this paper is classified as a Normative Legal research, which is based on primary and secondary legal materials. The approach taken was the statutory and the analytical conceptual approach.

The research results indicate that with the withdrawal of leasing object in a lease agreement by the creditor according to law (under the provisions of Article 1338 of Indonesian Civil Code) can be justified and lawful. The agreement of waiving the provisions of article 1266 of paragraph 2 of Indonesian Civil Code binding on the partie based on the principle of freedom of contract.
\end{abstract}

Keywords: Withdrawal of leasing goods, Leasing, Default. 


\section{PENDAHULUAN}

Dengan perkembangan

Bangsa Indonesia yang sangat komplek dan dipengaruhi oleh arus globalisasi serta bersifat multidimensi tidak terlepas dari tujuan pembangunan nasional bangsa Indonesia yaitu untuk mewujudkan masyarakat yang merata , meteriil dan spiritual berdasarkan Pancasila yang sejalan dengan tujuan bangsa Indonesia yang terdapat dalam pembukaan UUD 1945 serta segala usaha harus dapat dimanfaatkan sebesarbesarnya untuk kepentingan rakyat, dalam mencapai tujuan tersebut bangsa Indonesia melaksanakan pembangunan yang tidak terlepas dari pengaruh arus globalisasi

Di era globalisasi ini pertumbuhan ekonomi demikian meningkat yang akhirnya akan mengakibatkan tingginya persaingan dalam dunia bisnis. Kegiatan bisnis itu sendiri selalu berkaitan dengan bidang ekonomi.

Adanya peningkatan daya saing global perekonomian nasional secara keseluruhan tidak terlepas dari peran serta para pelaku ekonomi baik dari segi perorangan maupun kelompok yang mempunyai tujuan untuk memperoleh keuntungan. Para pelaku ekonomi sangat beraneka ragam dan bervariasi dalam menentukan eksistensinya maupun dalam kedudukan institusinya. Kegiatan atau aktivitas dibidang ekonomi yang melibatkan para pelaku ekonomi Kegiatan dibidang ekonomi tersebut dilakukan tidak saja melibatkan orang perorangan, tetapi juga melibatkan perusahaan, termasuk pemerintah, baik langsung maupun tidak langsung saling bersaing dalam memasarkan barang.

Perekonomian nasional digerakkan oleh para pelaku ekonomi, yang salah satunya hanya untuk memperoleh keuntungan. ${ }^{1}$ Peran serta para pelaku ekonomi melakukan kegiatan ekonomi dengan berbagai macam cara dan menggunakan bentuk usaha yang bervariasi dengan berbagai macam transaksi.

Menurut Sadono Sukirno, di dunia ini terdapat berjuta-juta manusia dan setiap orang

1 Neny Sri Imaniyati, 2009, Hukum Bisnis Telaah Tentang Pelaku dan Kegiatan Ekonomi, Graha Ilmu, Yogyakarta, hal. 1 
melakukan kegiatan ekonomi yang berbeda satu dengan yang lainnya, dan tidak mungkin menyebutkan kegiatan mereka satu persatu. Pelaku ekonomi dibedakan menjadi tiga golongan, yaitu rumah tangga, perusahaan, dan pemerintah. ${ }^{2}$

Suatu hal yang pasti, perkembangan di bidang ekonomi telah mendorong munculnya berbagai macam transaksi yang bermotif ekonomi yang melibatkan para pelaku ekonomi baik orang perorangan maupun badan usaha (perusahaan).

Berkaitan dengan kegiatan ekonomi, dalam konteks sistem ekonomi, pada dasarnya ada tiga kegiatan yang menjadi karakter sistem ekonomi, yaitu produksi, distribusi, dan konsumsi. Adapun arti dan makna dari kegiatan dimaksud dapat dijelaskan sebagai berikut :

1. Produksi, merupakan suatu kegiatan yang dilakukan untuk menambah nilai guna suatu benda atau menciptakan benda baru Sadono Sukirno, 1985 Pengantar Teori Mikro Ekonomi, FE, Universitas Indonesia, Jakarta, hal. 5. sehingga lebih bermanfaat dalam memenuhi kebutuhan, kegiatan menambah guna suatu benda tanpa mengubah bentuknya dapat dikatakan produk jasa , sedangkan kegiatan menambah daya guna suatu benda dengan mengubah sifat dan bentuknya dinamakan produksi barang. Produksi dapat diartikan pula sebagai upaya manusia menciptakan kekayaan dengan cara memanfaatkan sumber alam. Kegiatan produksi adalah kegiatan membuat dan menghasilkan produk barang dan/atau jasa. Dalam produksi ada empat faktor penting, yaitu faktor alam, tenaga kerja, modal dan manajemen.

2. Distribusi merupakan kegiatan merupakan kegiatan ekonomi pemasaran yang berusaha memperlancar dan mempermudah penyampaian barang dan jasa dari produsen kepada konsumen sehingga penggunaannya sesuai dengan yang diperlukan, lebih lanjut distribusi merupakan 
kegiatan produksi, yakni produk yang dihasilkan dari kegiatan produksi itu kemudian disebarkan dan dipindah tangankan dari satu pihak ke pihak lainnya. Mekanisme yang digunakan dalam distribusi ialah dengan cara pertukaran antara hasil produksi dengan alat tukar (uang). ${ }^{3}$

3. Konsumsi, berarti mengambil manfaat atau menggunakan barang-barang dari hasil produksi. Kegiatan ekonomi pada hakekatnya adalah kegiatan penyeimbang dari kegiatan produksi, artinya kegiatan produksi tidak akan mengandung arti apa-apa bagi kehidupan ekonomi manusia, jika tidak diikuti dengan kegiatan konsumsi, sebab pada hakekatnya kegiatan produksi dilakukan dalam rangka memenuhi kebutuhan konsumsi, sebab konsumsi merupakan kurangnya atau habisnya daya suatu benda atau jasa Op.Cit, hal. 66 .
${ }^{3}$ Neny Sri Imaniyati, untuk memenuhi kebutuhan atau kepuasan seseorang.

Kegiatan ekonomi yang menyangkut produksi, distribusi dan konsumsi sebagaimana dimaksud juga berkaitan dengan transaksi dibidang sewa beli yang dasar transaksinya adalah perjanjian, dimana pembeli sewa dapat memiliki barang dengan pembayarannya secara angsuran dengan jangka waktu tertentu.

Hasil produksi yang
didistribusikan atau dibawa
kepasaran sudah barang tentu
guna memenuhi kepentingan
konsumsi. Guna memperoleh atau
mendapatkan hasil produksi
tersebut, maka ada konsumen
(pembeli) yang mampu
membelinya secara tunai dan ada pula yang hanya mampu memperoleh hasil produksi tersebut dengan membeli yang pembayarannya dicicil/diangsur secara berkala.

Kegiatan ekonomi pada umumnya dilakukan oleh pelakupelaku ekonomi baik orang perorangan yang menjalankan perusahaan maupun badanbadan usaha baik yang berbadan hukum maupun yang tidak 
berbadan hukum. ${ }^{4}$ Selain itu, kegiatan ekonomi juga ditandai dengan adanya berbagai transaksi dibidang perdagangan (jual beli) barang dan atau jasa dengan tujuan memperoleh keuntungan.

Perkembangan perekonomian di Indonesia diikuti pula oleh perkembangan berbagai bentuk transaksi, misalnya ; sewa guna usaha (leasing), jual beli angsuran, maupun sewa beli. Hal ini terjadi karena konsumen atau pembeli memiliki dana terbatas. ${ }^{5}$

Perjanjian sewa beli di indonesia cukup berkembang dapat dilihat dalam keseharian kehidupan masyarakat, masyarakat lebih antusias memenuhi kebutuhan sekundernya yaitu dengan cara mudah hanya memenuhi berupa persyaratan seperti kartu identitas

4 Sri Redjeki Hartono, 2000, Kapita Selekta Hukum Ekonomi, Mandar Maju, Bandung, hal. 4.

5 Sri Gambir Melati Hatta, 1999, Beli Sewa Sebagai Perjanjian Tak bernama : Pandangan Masyarakat dan Sikap Mahkamah Agung, Alumni, Bandung, hal. 1. saja berupa KTP saja sudah langsung mendapatkan barang yang diinginkan hal ini yang membuat perjanjian sewa beli cepat berkembang, akan tetapi dengan berkembangan yang cepat pula tidak dibarengi dengan perangkat peraturan perundangundangan yang cukup memadai kurangnya aturan-aturan yang tegas mengenai perjanjian sewa beli, kurangnya pengawasan terhadap para calon pembeli dalam hal calon pembeli membeli barang dengan cara mengkredit atau mencicil seperti contoh yang telah dilakukan oleh beberapa bank-bank di indonesia ketika mereka akan mengadakan perjanjian pinjam meminjam uang terlebih dahulu pihak bank sendiri memberikan berupa surat pernyataan kepada calon debitur apakah calon debitur tersebut sudah pernah mengadakan perjanjian pinjam meminjam uang kepada bank lain atau belum disinilah perlunya pengawasan terhadap masyarakat yang akan membeli barang dengan cara mencicil agar nantinya tidak terjadi hal-hal yang tidak diinginkan misalnya terjadinya ketidakjujuran dari pihak pembeli 
atau yang disebut dengan wanprestasi yang mengakibatkan kerugian dari pihak penjual barang, dengan adanya ketidakjujuran dari pembeli (wanprestasi ) maka yang menjadi persoalannya adalah benda yang menjadi obyek dalam perjanjian tersebut.

Sebagaimana

juga

dibenarkan oleh Sri Gambir Melati Hatta dalam hasil penelitian bahwa pada umumnya persoalan dalam perjanjian sewa beli timbul apabila terjadi penarikan barang yang menjadi obyek perjanjian ketika pembeli wanprestasi. ${ }^{6}$ Penarikan menurut undangundang akan memerlukan waktu yang relative lama, karena harus melalui perintah Hakim. Guna menghindari hal itu, agar lebih efisien, sering pihak penjual menempuh jalan pintas dengan melakukan penarikan secara langsung, bahkan sering menggunakan orang yang bertindak sebagai debt collector untuk menarik barang obyek perjanjian dari tangan pihak pembeli. Walaupun hal itu Hatta, Op.Cit, hal. 10 dicantumkan dalam perjanjian, dapat diidentifikasi sebagai praktek perampasan, mengingat belum adanya peraturan hukum yang khusus mengatur sewa beli, maka pengaturan hak dan kewajiban pihak-pihak diatur dalam perjanjian yang dibuat oleh para pihak sendiri. Syarat-syarat dalam perjanjian lebih banyak didominasi oleh kepentingan penjual dengan mengabaikan hak-hak pembeli.

Sewa Beli berdasarkan Keputusan Menteri Perdagangan dan Koperasi No. 34/KP/II/80 tanggal 1 Pebruari 1980 tentang Perizinan Kegiatan Usaha Sewa Beli (here purchase), jual beli dengan angsuran (credit sale) dan sewa (renting), diberikan pengertian Sewa Beli sebagai berikut :

Sewa Beli (here purchase) adalah jual beli barang dimana penjual melaksanakan penjualan barang dengan cara memperhitungkan setiap pembayaran yang dilakukan oleh pembeli yang dengan pelunasan atas harga barang yang telah disepakati bersama dan yang diikat dalam suatu perjanjian, serta hak milik atas barang tersebut baru beralih 


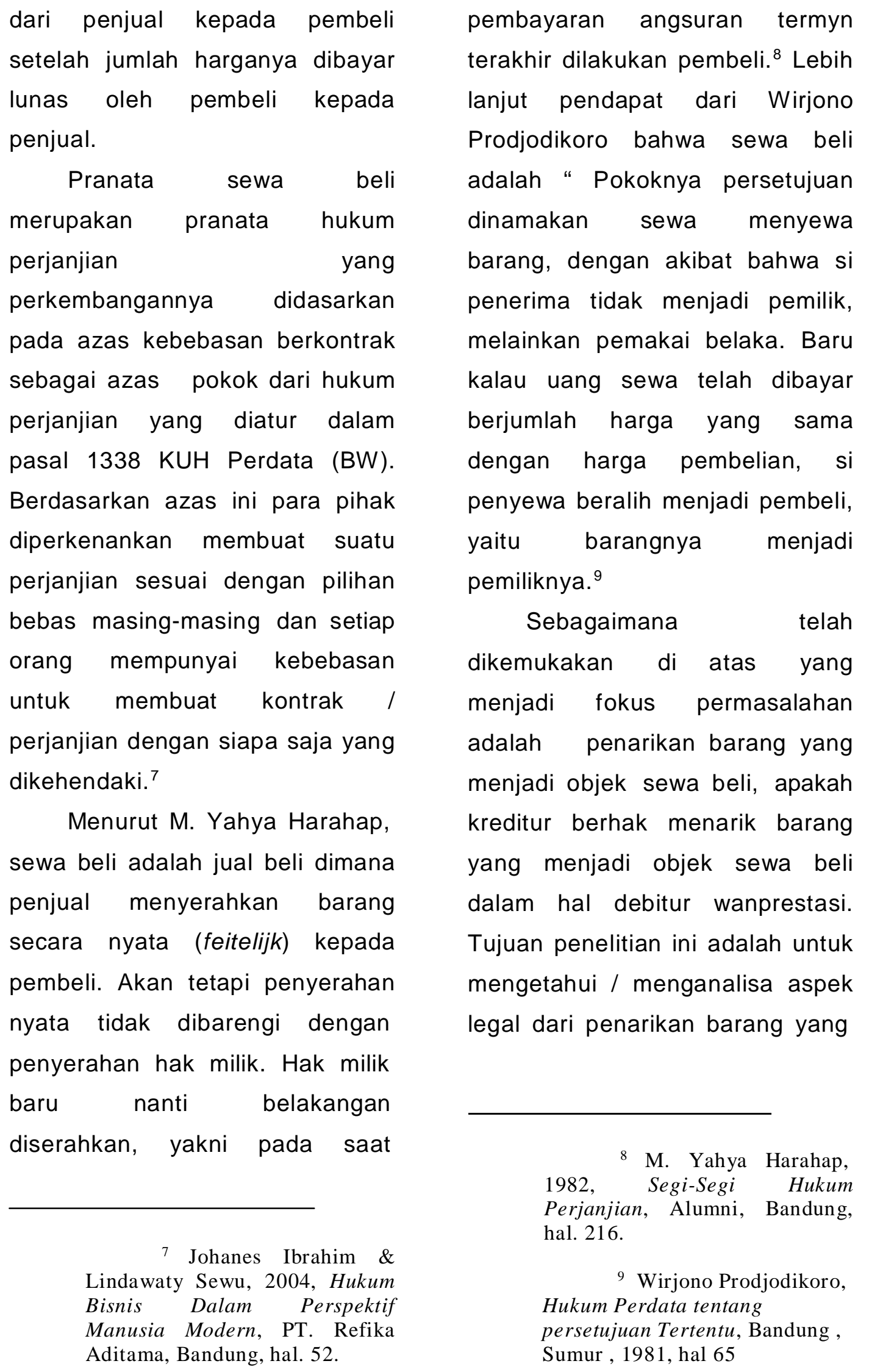


menjadi objek sewa beli dalam hal debitur wanprestasi

\section{METODE PENELITIAN}

Dalam penelitian ini menggunakan penelitian hukum normatif, yaitu suatu prosedur penelitian ilmiah untuk menemukan kebenaran berdasarkan logika kelimuan dari sisi normatif. ${ }^{10}$ Bahan hukum yang dipergunakan terdiri dari bahan hukum primer serta bahan hukum sekunder. Bahan hukum primer, yaitu bahan-bahan hukum berupa peraturan perundang-undangan, catatan-catatan resmi atau risalah dalam pembuatan perundangundangan dan putusan-putusan hakim. ${ }^{11}$ Bahan hukum sekunder, yaitu bahan hukum yang memberikan penjelasan terhadap bahan hukum primer, yaitu meliputi; buku-buku, literatur, artikel, makalah dan bahan-bahan

\begin{tabular}{|c|c|c|}
\hline $\begin{array}{l}1985, \\
\text { Normatif } \\
\text { Singkat, } \\
\text { h. } 15 \text {. }\end{array}$ & $\begin{array}{c}\text { Soerjono } \\
\text { Penelitian } \\
\text { Suatu } \\
\text { CV. Rajawal }\end{array}$ & $\begin{array}{r}\text { Soekanto, } \\
\text { Hukum } \\
\text { Tinjauan } \\
\text { li, Jakarta }\end{array}$ \\
\hline 11 & Peter & Mahmud \\
\hline Marzuki, & 2007 , & Penelitian \\
\hline Hukum, & Cet. 3, & Kenc \\
\hline renada & edia Group & \\
\hline
\end{tabular}

tertulis lainnya dari para ahli hukum. Dalam penulisan ini bahan hukum primer yang dikaji terdiri dari KUH Perdata UU perlindungan Konsumen No. 8 tahun 1999, Pendekatan terhadap permasalahan dilakukan dengan pendekatan perundangundangan (statue approach) dan pendekatan analisis konsep hukum (analitical conceptual approach).

\section{HASIL DAN PEMBAHASAN}

Perjanjian Sewa Beli Sebagai Perjanjian Standar.

Bentuk pranata atau lembaga sewa beli sesungguhnya merupakan bentuk lain dari jual beli dengan cara kredit. Pranata sewa beli ini merupakan suatu terobosan dari pranata jual beli pada umumnya. Bila dilihat dari segi bentuknya, perjanjian sewa beli itu berbentuk perjanjian standar (perjanjian baku).

$$
\text { Perjanjian standar telah }
$$

menjadi bagian dari praktek bisnis di indonesia. Banyak transaksi dibidang bisnis dituangkan dalam bentuk perjanjian standar. Perjanjian standar itu sendiri sebenarnya telah dikenal sejak jaman Yunani kuno. Dalam 


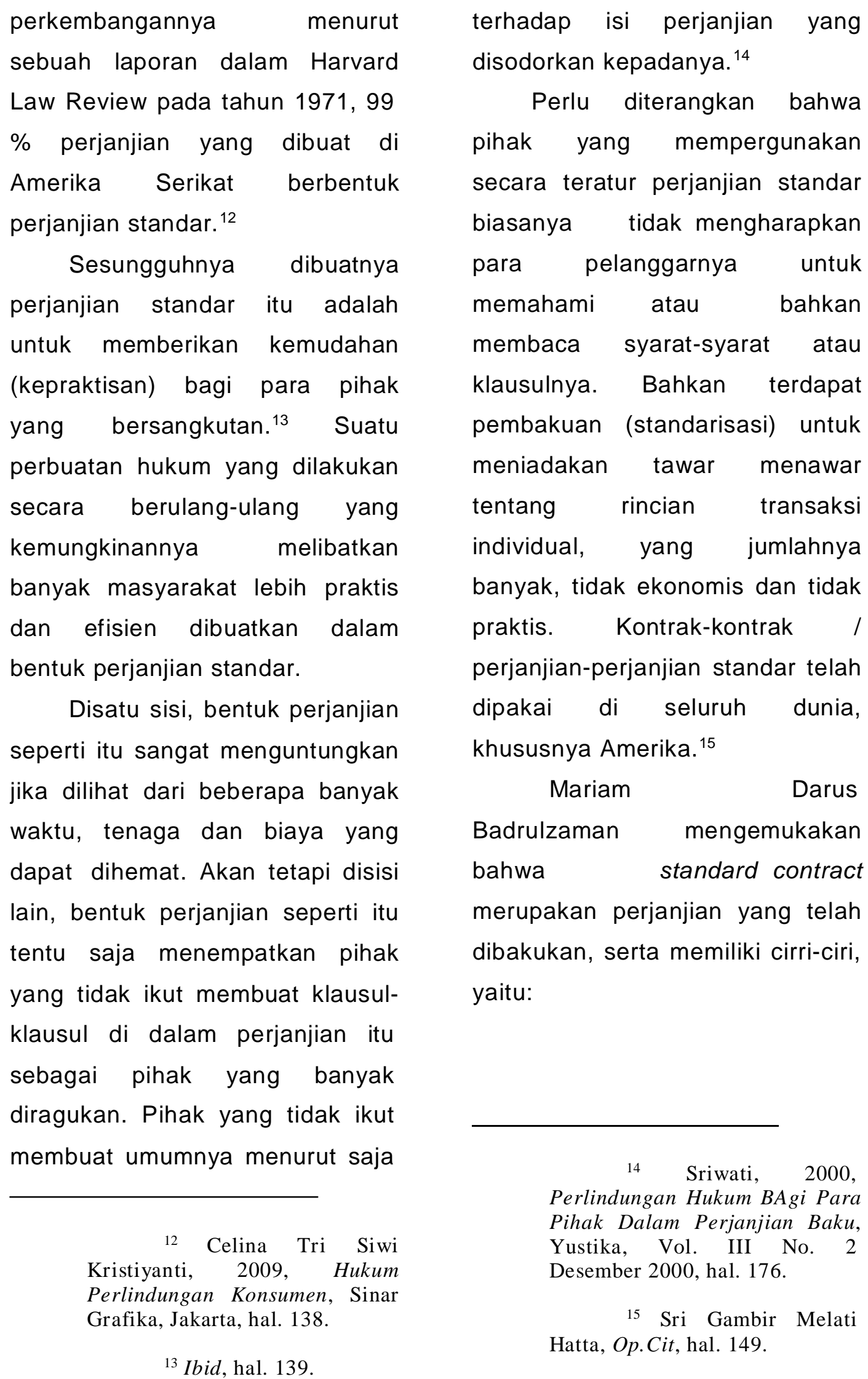


1. Isinya ditetapkan secara

Suatu perjanjian yang sepihak oleh pihak yang posisinya ekonominya kuat;

2. Masyarakat (debitur) sama sekali tidak ikut dalam menentukan isi perjanjian;

3. Terdorong oleh kebutuhan debitur terpaksa menerima perjanjian tersebut;

4. Bentuknya tertentu (tertulis);

5. Dipersiapkan secara massal dan kolektif. ${ }^{16}$

Penggunaan perjanjian standar itu boleh dikatakan sudah bersifat universal, hampir di berbagai negara di dunia sudah umum dipergunakan, tidak terkecuali Indonesia. Menyikapi fenomena tersebut tentu saja dipandang perlu untuk mengantisipasi berbagai persoalan hukum yang muncul berkaitan dengan perumusan dan pelaksanaan perjanjian standar itu, termasuk perjanjian standar sewa beli.

Wanprestasi Dalam Perjanjian Sewa

Menurut

Wirjono

Prodjodikoro, wanprestasi berarti ketiadaan suatu prestasi. Beliau mengkaitkan masalah wanprestasi dengan prestasi perjanjian, sehingga mengartikan wanprestasi sebagai ketiadaan pelaksanaan janji. ${ }^{18}$

Begitu juga Yahya Harahap, memberikan pengertian wanprestasi yaitu pelaksanaan kewajiban yang tidak tepat pada

${ }^{17}$ Agus Yudha Hernoko, 2008, Hukum Perjanjian Azas Proposionlitas dalam Kontrak Komerial, Laks Bang Mediatama, Yogyakarta.

${ }^{18}$ Wirjono Prodjodikoro I, Op.Cit, hal. 44 
waktunya atau dilakukan tidak menurut selayaknya, sehingga debitur yang wanprestasi bila ia telah Ialai, terlambat dari jadwal waktu pelaksanaan prestasi yang ditentukan, atau melaksanakan prestasi, tetapi tidak menurut sepatutnya atau selayaknya. ${ }^{19}$

\section{Sedangkan}

Abdulkadir

Muhammad menyebutkan

wanprestasi adalah tidak memenuhi kewajiban yang telah ditetapkan dalam perikatan, baik perikatan yang timbul karena perjanjian maupun perikatan yang timbul karena undang-undang. ${ }^{20}$

Untuk menentukan apabila seorang debitur itu bersalah melakukan wanprestasi, perlu ditentukan dalam keadaan bagaimana seorang debitur itu dikatakan sengaja atau lalai tidak memenuhi prestasi.

\begin{tabular}{ll}
\multicolumn{1}{c}{ Abdulkadir } & Muhammad \\
membedakan & wanprestasi \\
menjadi tiga yaitu : &
\end{tabular}
60

${ }^{19}$ Yahya Harahap, Op.Cit, hal.

\footnotetext{
${ }^{20}$ Abdulkadir

Muhammad,Perjanjian Baku

Dalam Praktek Perusahaan Perdagangan, PTCitra Adiyta Bakti, Bandung.
}

1. Debitur tidak memenuhi prestasi sama sekali, artinya debitur tidak memenuhi kewajiban yang telah disanggupinya untuk dipenuhi dalam suatu perjanjian, atau tidak memenuhi kewajiban yang ditetapkan undangundang dalam perikatan yang timbul karena undangundang.

2. Debitur memenuhi prestasi, tetapi tidak baik atau keliru. Disini debitur melaksanakan atau memenuhi apa yang diperjanjikan atau apa yang ditentukan oleh undangundang, tetapi tidak sebagaimana mestinya menurut kualitas yang ditentukan dalam perjanjian atau menurut kualitas yang ditetapkan undang-undang.

3. Debitur memenuhi prestasi, tetapi tidak tepat pada waktunya. Disini debitur memenuhi prestasi tetapi terlambat waktu yang ditetapkan dalam perjanjian tidak dipenuhi.

Sedangkan R. Subekti, menyebutkan wanspretasi seorang debitur dapat berupa empat macam : 
a. Tidak melakukan apa yang disanggupi akan dilakukannya.

b. Melaksanakan apa yang dijanjikannya, tetapi tidak sebagaimana dijanjikan (tidak sempurna).

c. Melakukan apa yang dijanjikannya, tetapi terlambat.

d. Melakukan sesuatu yang menurut perjanjian tidak boleh dilakukannya. ${ }^{21}$

Wanprestasi bisa juga terjadi pada perjanjian sewa beli, dimana pihak pembeli sewa tidak melaksanakan pembayaran kewajiban sewa yang telah disepakati dalam perjanjian terhadap penjual sewa. Keadaan seperti itu dapat menimbulkan berbagai akibat hukum. Suatu tindakan wanprestasi membawa konsekuensi terhadap timbulnya hak menuntut ganti rugi dari pihak yang dirugikan kepada pihak yang melakukan wanprestasi.

Penarikan Barang yang menjadi Objek Sewa Beli dalam hal Pembeli Sewa Wanprestasi

Salah satu akibat hukum wanprestasi dalam perjanjian sewa beli adalah dimana barang

${ }^{21}$ R. Subekti II, Op.Cit. hal. 45 yang menjadi objek sewa beli akan ditarik oleh penjual sewa, sudah menjadi fakta yang tidak bisa dibantah apabila pembeli sewa tidak memenuhi kewajibannya membayar angsuran / cicilan harga sewa yang telah disepakati dalam perjanjian, maka barang yang menjadi objek sewa beli ini akan ditarik dari tangan pembeli sewa.

Penarikan barang objek sewa beli sesungguhnya merupakan alternatif terakhir setelah berbagai upaya dilakukan agar pembeli sewa mau melaksanakan kewajibannya secara sadar dan penuh tanggung jawab. Apabila segala upaya sudah dilakukan oleh penjual sewa tidak membuahkan hasil, barulah dilakukan langkah terakhir berupa penarikan barang yang menjadi objek sewa beli tersebut.

Dalam perjanjian sewa beli hak milik atas barang masih berada pada penjual sewa sebelum harga dilunasi pembeli sewa, dengan demikian penjual sewa berhak menarik kembali barang tersebut dari penguasaan pembeli sewa, jika pembeli sewa 
wanprestasi dalam melakukan cicilan pembayaran harga. ${ }^{22}$

Dari segi perjanjian, yaitu perjanjian sewa beli yang dibuat oleh para pihak, ada sarjana yang berpendapat, bahwa adanya penarikan barang yang menjadi objek sewa beli oleh penjual sewa dalam hal pembeli sewa wanprestasi tidak dapat dibenarkan oleh hukum, karena bertentangan dengan ketentuan Pasal 18 ayat 1 huruf $d$ Undangundang Nomor 8 tahun 1999 tentang Perlindungan Konsumen. Ketentuan Pasal mana menegaskan :

Pelaku usaha dalam menawarkan barang dan atau jasa yang ditujukkan untuk diperdagangkan dilarang membuat atau mencantumkan klausul baku pada setiap dokumen dan atau perjanjian apabila menyatakan pemberian kuasa dari konsumen kepada pelaku usaha, baik secara langsung maupun tidak langsung untuk melakukan segala tindakan

\footnotetext{
${ }^{22}$ Suharnoko 2007 ,Hukum Perjanjian Teori dan Analisa Kasus, Prenada Media Group, Jakarta, hal 73
}

sepihak yang berkaitan dengan barang yang dibeli oleh konsumen secara angsuran.

Dengan berlakunya Undangundang Perlindungan Konsumen No. 8 Tahun 1999, disebutkan dalam Pasal 18 ayat i huruf $d$, bahwa pelaku usaha dilarang mencantumkan klausul baku yang menyatakan bahwa pelaku usaha berhak mengambil tindakan sepihak atas barang yang dibeli konsumen secara angsuran. Klausul seperti itu, menurut ketentuan Pasal 18 ayat 3 Undang-undang No. 8 Tahun 1999 adalah batal demi hukum.

Seperti telah dikemukakan pada uraian sebelumnya bahwa perjanjian sewa beli antara penjual sewa sebagai pelaku usaha dan pembeli sewa sebagai konsumen dibuat dalam bentuk kontrak / perjanjian standard yang dibuat dan didesain oleh penjual sewa.

Dalam perjanjian tersebut dicantumkan suatu klausul bahwa para pihak melepaskan ketentuan Pasal 1266 KUH Perdata, sebingga akibat hukumnya penjual sewa dapat menarik kembali barangnya tanpa melalui Putusan Hakim, karena dengan 
adanya atau terjadinya wanprestasi Perjanjian Sewa beli dianggap batal demi hukum.

Penarikan barang sewa beli menurut hemat penulis tidak dapat dibenarkan menurut hukum karena :

1. bertentangan dengan Pasal 18 huruf d yang menyatakan pemberian kuasa dari konsumen kepada pelaku usaha baik secara langsung maupun tidak langsung untuk melakukan segala tindakan sepihak yang berkaitan dengan barang yang dibeli oleh konsumen secara angsuran.

Demikian

Undang-undang N0. 8 tahun 1999 tentang perlindungan konsumen yang intinya pelaku usaha dalam menawarkan barang dan/atau jasa yang ditujukan untuk diperdagangkan dilarang membuat atau mencantumkan klausula baku pada setiap dokumen dan / atau perjanjian apabila :

a. Menyatakan pengalihan tanggung jawab pelaku usaha;

b. Menyatakan bahwa pelaku usaha berhak menolak penyerahan kembali barang yang dibeli konsumen;

c. Menyatakan bahwa pelaku usaha berhak menolak penyerahan kembali uang yang dibayarkan atas barang dan / atau jasa yang dibeli oleh konsumen;

d. Menyatakan pemberian kuasa dari konsumen kepada pelaku usaha baik secara langsung maupun tidak langsung untuk melakukan segala tindakan sepihak yang berkaitan dengan barang yang dibeli oleh konsumen secara angsuran;

e. Mengatur perihal pembuktian atas hilangnya kegunaan barang atau pemanfaatan jasa yang dibeli oleh konsumen;

f. Memberikan hak kepada pelaku usaha untuk mengurangi manfaat jasa atau mengurangi harta kekayaan konsumen yang menjadi objek jual beli jasa;

g. Menyatakan tunduknya konsumen kepada peraturan yang berupa aturan baru, tambahan, Ianjutan dan /atau pengubahan lanjutan yang dibuat sepihak oleh pelaku 
usaha dalam masa konsumen memanfaatkan jasa yang dibelinya;

h. Menyatakan

bahwa konsumen memberi kuasa kepada pelaku usaha untuk pembebanan hak tanggungan, hak gadai, atau hak jaminan terhadap barang yang dibeli oleh konsumen secara angsuran.

2. Pasal 1266 dalam kitab Undang-undang Hukum Perdata yang intinya, syarat batal dianggap selalu dicantumkan dalam persetujuan-persetujuan yang bertimbal balik, manakala salah satu pihak tidak memenuhi kewajibannya.

3. Pasal $1338 \mathrm{KUH}$ Perdata yang menyatakan semua perjanjian yang dibuat secara sah berlaku sebagai undangundang bagi mereka yang membuatnya. Sebagaimana dikatakan bahwa inti dari Pasal 1338 adalah para pihak dalam melakukan suatu perjanjian tidak boleh bertentangan dengan Undang-undang dan ketertiban umum.
Mencermati pasal ini itu berarti dalam kontrak perjanjian sewa beli para pihak tidak boleh mengabaikan ketentuan pasal 1266 karena pasal tersebut merupakan ketentuan undangundang. Dengan demikian perbuatan yang mengambil tindakan secara sepihak tidak dapat dibenarkan.

Persoalannya sekarang apakah tindakan penjual sewa menarik barang objek sewa beli tersebut dapat dibenarkan menurut hukum? Hal ini perlu mendapatkan kejelasan bila dilihat ketentuan Pasal 1338 KUH Perdata, bahwa setiap perjanjian yang dibuat secara sah berlaku sebagai Undangundang sepanjang tidak melanggar Undang-undang dan ketertiban umum. Pasal 1266 KUH Perdata, mempunyai kekuatan mengikat dan harus ditaati oleh para pihak. Dengan demikian, penarikan barang yang menjadi objek sewa beli tidak mendapat pembenaran bila dilihat pada ketentuan pasal $1338 \mathrm{KUH}$ Perdata, bahwa setiap perjanjian yang dibuat secara sah berlaku sebagai undang-undang bagi para 




Kesimpulan

Tindakan penarikan barang yang menjadi obyek perjanjian sewa beli oleh penjual sewa 


\section{DAFTAR BACAAN}

Abdulkadir Muhammad, Perjanjian
Baku Dalam Praktek
Perusahaan Perdagangan ,
PTCitra Adiyta Bakti,
Bandung.

Agus Yudha Hernoko, 2008, Hukum Perjanjian Azas Proposionlitas dalam Kontrak Komerial, Laks Bang Mediatama, Yogyakarta.

Celina Tri Siwi Kristiyanti, 2009, Hukum Perlindungan Konsumen, Sinar Grafika, Jakarta.

Johanes Ibrahim \& Lindawaty Sewu, 2004, Hukum Bisnis Dalam Perspektif Manusia Modern, PT. Refika Aditama, Bandung.

M. Yahya Harahap, 1982, SegiSegi Hukum Perikatan, Alumni, Bandung.

Mariam Darus Badrulzaman, 1991, Perjanjian Kredit Bank, PT. Citra Aditya Bakti, Bandung.

Peter Mahmud Marzuki, 2007, Penelitian Hukum, Cet. 3, Kencana Prenada Media Group, Jakarta.

$\begin{array}{ll}\text { - 1996, Kitab Undang- } \\ \text { Undang Hukum Perdata } \\ \text { Buku III tentang Hukum } \\ \text { Perikatan } & \text { Dengan } \\ \text { Penjelasan, } & \text { Alumni, } \\ \text { Bandung. } & \end{array}$

Sadono Sukirno, 1985, Pengantar Teori Mikro Ekonomi, FE, Universitas Indonesia, Jakarta.

Soerjono Soekanto, 1985, Penelitian Hukum Normatif Suatu Tinjauan Singkat, CV. Rajawali, Jakarta.

Sri Gambir Melati Hatta, 1999, Beli Sewa Sebagai Perjanjian Tak bernama : Pandangan Masyarakat dan Sikap Mahkamah Agung, Alumni, Bandung.

Sri Redjeki Hartono, 2000, Kapita Selekta Hukum Ekonomi, Mandar Maju, Bandung.

Sriwati, 2000, Perlindungan Hukum Bagi Para Pihak Dalam Perjanjian Baku, Yuridika, Vol. III No. 2 Desember 2000.

Wirjono Prodjodikoro, 1965, Penelitian Perdata tentang persetujuan Tertentu Tertentu, Sumur Bandung.

\section{Artikel / Makalah / Jurnal}

Abdullah, 2006, Peran Notaris Dalam Pembuatan Kontrak Bisnis, Makalah yang disajikan dalam Workshop Pengembangan Unit Revenue Generating untuk Memacu Peningkatan Kualitas Akademik Melalui Program Layanan Kepakaran Legal Aspek Industri dan Sektor Usaha, Pada program Studi Hukum Bisnis, Fakultas Hukum TFSDP, BATCH III, 


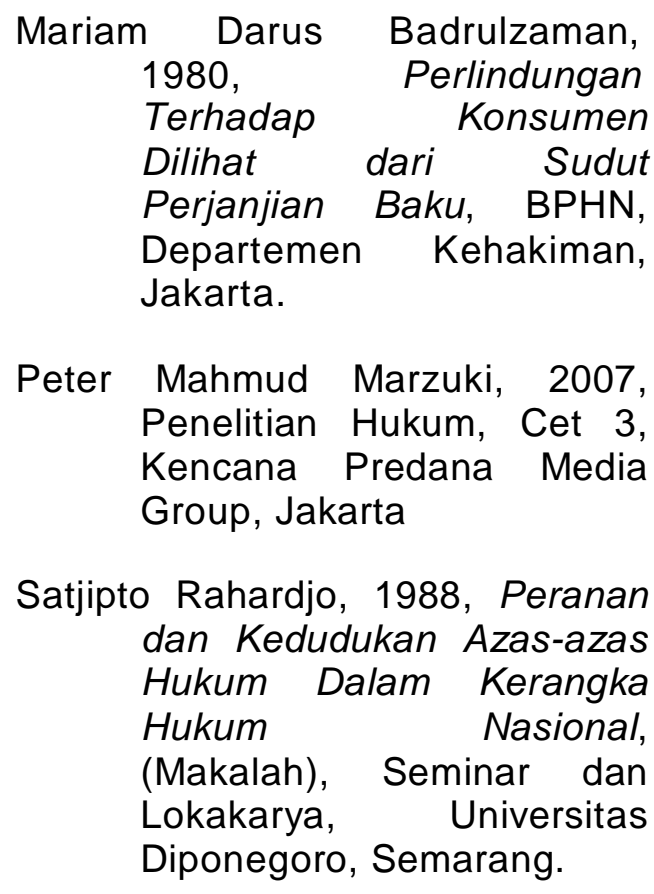

\begin{tabular}{|c|c|}
\hline Peratu & $\begin{array}{l}\text { ran } \\
\text { Undangan }\end{array}$ \\
\hline Kitab & $\begin{array}{l}\text { Undang-Undang Hukum } \\
\text { Perdata } \quad \text { (Burgerlijke } \\
\text { Wetboek) }\end{array}$ \\
\hline Undan & $\begin{array}{lcc}\text { g-undang } & \mathrm{RI} & \text { Nomor } 8 \\
\text { Tahun } 1999 & \text { tentang } \\
\text { Perlindungan Konsumen }\end{array}$ \\
\hline Surat & 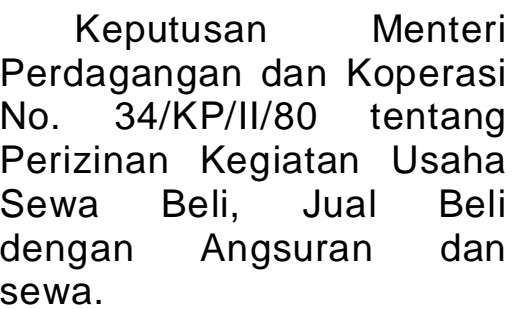 \\
\hline
\end{tabular}

